ORIGINAL RESEARCH

\title{
Microbiological quality of artisanal Sepet cheese
}

\author{
DUYGU ERCAN, ${ }^{1}$ FIGEN KOREL ${ }^{1} *$ and HANDE ORŞAHIN ${ }^{2}$ \\ ${ }^{1}$ Department of Food Engineering, Izmir Institute of Technology, Urla, İzmir 35430, Turkey, and ${ }^{2}$ Biotechnology and \\ Bioengineering Program, İzmir Institute of Technology, Urla, İzmir 35430, Turkey
}

Microbial diversity in milk and in cheese itself affects the biochemical and sensory characteristics of artisanal cheeses. In this study, the microflora of Sepet cheese, which is a traditional artisanal cheese in Turkey, was investigated. Average lactococci, lactobacilli, enterococci, yeast, mould, coliform, psychrotrophic and total aerobic bacteria, presumptive Staphylococcus aureus counts were; $7.31 \pm 1.08, \quad 7.19 \pm 1.02, \quad 6.84 \pm 0.92, \quad 3.19 \pm 1.40, \quad 0.84 \pm 0.89, \quad 2.18 \pm 1.81, \quad 4.92 \pm 1.15$, $7.53 \pm 1.13$ and $1.25 \pm 1.70 \log \mathrm{cfu} / \mathrm{g}$, respectively. Staphylococci, coliform and mould counts were less than $1.00 \log \mathrm{cfu} / \mathrm{g}$ at the end of ripening, which was at around $6-8{ }^{\circ} \mathrm{C}$ for 3 months. According to phenotypic and genotypic identifications, isolates were closely related to Lactobacillus plantarum, Weisella confusa, Weisella paramesenteroides, Pediococcus pentasaceous, Enterococcus casseliflavus, Enterococcus durans and Enterococcus faceium. This study provides baseline data on the microflora of traditional artisanal Sepet cheese, which is a prerequisite for a successful scale up to industrial production.

Keywords Sepet cheese, Microbiological count, Identification, Lactic acid bacteria.

\section{INTRODUCTION}

Milk is a nutritious food for humans, but milk is also a suitable growth medium for micro-organisms. Contaminated milk can spoil easily and may pose a health hazard if pathogens are present in milk. Therefore, various preservation processes are applied to raw milk to process it into microbiologically safe dairy products. Cheesemaking is a traditional milk preservation process, and cheese has an important place in the food culture of rural regions (Dost et al. 2004). Kamber (2008b) stated that $60 \%$ of the cheeses produced in Turkey were estimated as White Cheese, $17 \%$ of them were Kashar Cheese, $12 \%$ of them were estimated as Tulum and Mihalic Cheese, and $11 \%$ of production was estimated as other local cheeses. Sepet cheese ('sepet' in Turkish translates as 'basket' in English) is one of the traditional artisanal cheeses produced in the Aegean region in Turkey. In the production of Sepet cheese, raw goat milk is traditionally used. The artisanal process starts with heating the milk to $30-40{ }^{\circ} \mathrm{C}$ and the addition of rennet. After renneting, the heat is turned off and the milk is allowed to set for approximately $2 \mathrm{~h}$. When the coagulum becomes firm, it is cut with a fork or a pine tree branch until no large lumps of curd remain (Kını et al. 1999; Kamber 2008a). The curds are separated from the whey with a strainer, and approximately $1 \mathrm{~kg}$ of curd is placed into baskets, which are woven from stalks collected near rivers. The curd is left in the basket at ambient temperature $\left(20-24{ }^{\circ} \mathrm{C}\right)$ to drain by itself, and the soft curd assumes the shape of the basket. The curd is turned upside down to enable even whey drainage and so that all surfaces take the shape of the basket (Kamber 2008a). The curd is then removed from the basket, and the upper and lower surfaces are sprinkled with fine salt (approximately $30 \mathrm{~g}$ salts $/ \mathrm{kg}$ curd). Then, the salted curd is returned to the basket for further drainage at room temperature $\left(20-24{ }^{\circ} \mathrm{C}\right)$ (Büke 1981; Kınık et al. 1999). Approximately $18 \mathrm{~h}$ later, when the curd has knitted together to form a block, it is taken out of the basket and placed in a brine $(14 \%(\mathrm{w} / \mathrm{w}) \mathrm{NaCl})$ at around $6-8{ }^{\circ} \mathrm{C}$ for ripening and storage. The ripening time varies between 3 months to 12 months. The cheese could be stored in brine until consumption. Ercan et al. (2011) investigated the chemical, textural and sensorial characteristics of Sepet cheese and found that Sepet cheese is a 
semihard cheese according to IDF (1981). The average dry matter, fat-in-dry matter, protein, salt-in-dry matter, water activity, $\mathrm{pH}$, titratable acidity, ripening and lipolysis indices of Sepet cheese were reported as $55.16 \%, 45.80 \%, 29.18 \%$, $12.88 \%, 0.83,5.50,1.69 \%, 11.06$ and 6.36 , respectively (Ercan et al. 2011). Descriptors such as free fatty acid, animal like, sulphurous, creamy, cooked, whey aroma and salty basic taste have been used to describe the flavour of Sepet cheese. The most abundant volatile compounds in Sepet cheese were reported to be hexanoic, octanoic, decanoic and butyric acids, which were responsible for the cheesy, waxy and goaty odours (Ercan et al. 2011).

Microbial diversity in the raw milk and in cheese affects the flavour and texture of cheese. The micro-organisms may contribute directly through their metabolic activity or they may release enzymes, and those enzymes may cause changes in cheese texture or flavour (Beresford and Williams 2004). Mesophilic lactobacilli are reported as important nonstarter lactic acid bacteria in the maturation of cheeses because they can catabolise citrate and could be involved in proteolysis and in other enzymatic processes during cheese ripening (Crow et al. 2001; Terzic-Vidojevic et al. 2007). Moreover, nonstarter lactobacilli have lipase and esterase activities, which affect cheese flavour. Enterococcus spp. metabolise citrate and can form acetaldehyde, acetoin and diacetyl (Beresford and Williams 2004). Enterococcus spp. also contribute to cheese flavour by the hydrolysis of milk fat by lipases and esterases and the conversion of fatty acids into methyl ketones and thioesters (Tsakalidou et al. 1993; Giraffa 2003; Beresford and Williams 2004). Furthermore, some Enterococcus spp. are capable of producing a variety of bacteriocins, which can protect cheese against spoilage bacteria (Abdi et al. 2006). The natural microflora of cheese could become extinct, when artisanal cheesemaking is replaced by industrial scale processes. Therefore, it is important to document the natural biodiversity of artisanal cheese microflora. Some research on the microflora of traditional cheeses has been performed. For example; the natural microflora of artisanal Mexican Fresco and Manchego cheeses were investigated by Torres-Llanez et al. (2006) and Ballesteros et al. (2006). The increasing expansion of urbanisation and hence reduction in the rural population brings about a loss of expertise in traditional food-making technology such as cheesemaking. Many studies have shown that locally produced cheeses have different and typical microbial population dynamics related to the local production technology and environmental conditions (Boubekri and Ohta 1996; Terzic-Vidojevic et al. 2007). Pisano et al. (2006) and Williams and Withers (2010) conducted research to characterise Fiore Sardo, a traditional Sardinian cheese made from ewe's milk, and artisanal farmhouse cheeses manufactured in Scotland, respectively, to provide a better understanding of microbial diversity so that the typical characteristics of these cheeses can be retained, while at the same time, the microbiological quality can be improved.

The objectives of this study were (i) to investigate the lactic acid bacteria $(\mathrm{LAB})$ and quality indicator micro-organisms in the microflora of traditional artisanal Sepet cheeses collected from 11 different towns in the Aegean region of Turkey, (ii) to isolate and identify representative lactic acid bacteria in Sepet cheese and (iii) to investigate the changes in the counts from milk to curd and during the ripening of Sepet cheeses made on two different dairy farms.

\section{MATERIALS AND METHODS}

\section{Sampling}

In the first part of the study, the microflora of fifty-two Sepet cheeses, which were ripened approximately for 3 months, were investigated. The cheese samples were collected from small dairy farms and local bazaars located in Çeşme $(n=15)$, Karaburun $(n=7)$, Zeytineli $(n=3)$, Gülbahçe $(n=3)$, Germiyan $(n=3)$, Ovacık $(n=3)$, Barbaros $(n=3)$, Üçkuyular $(n=3)$, Kemalpaşa Turgutlu $(n=3)$, Tire $(n=3)$ and Ayvalık $(n=6)$, which are the towns in Aegean region of Turkey. Samples were taken to the laboratory in an ice box on the same day. They were stored at $4{ }^{\circ} \mathrm{C}$ prior to analysis and analysed in 2 days.

In the second part of the study, Sepet cheeses were produced using goat milk in local small dairy farms located in Germiyan and Zeytineli towns. The only difference between the production methods of Germiyan and Zeytineli cheeses was the type of coagulant, which was used during production. Microbial rennet (Mayasan Co. Inc., Istanbul, Turkey) was used as a coagulant agent in cheeses produced in Germiyan. Artisanal rennet, produced from the fourth stomach of young goats in the farm, was used in cheeses produced in Zeytineli. After cheeses were placed into brine for ripening, the cheese samples were transferred to laboratory and ripened an incubator at $8{ }^{\circ} \mathrm{C}$ for 3 months. Milk, curd, 1 day, and 1-, 2- and 3month-old cheeses were analysed to determine microbial counts and identify lactic acid bacterial species.

\section{Microbiological analysis}

Ten-mL samples of milk and 10-g samples of cheese or curd were homogenised into sterile $90-\mathrm{mL}$ solutions of $2 \%$ (w/v) sodium citrate at $45{ }^{\circ} \mathrm{C}$ using a stomacher device ( Interscience, Bagmixer 400W, Saint Dom, France), and decimal dilutions were prepared in sterile $0.1 \%(\mathrm{w} / \mathrm{v})$ peptone water (Psoni et al. 2003). The decimal dilutions of homogenates were used for bacterial enumeration. The total bacterial count (TBC) was measured on skim milk plate count agar (Merck, Darmstadt, Germany) after incubation at $32{ }^{\circ} \mathrm{C}$ for $72 \mathrm{~h}$. Lactococci were determined on M17 agar (Merck) after incubation at $37{ }^{\circ} \mathrm{C}$ for $48 \mathrm{~h}$. Lactobacilli were counted on MRS agar (Fluka, Saint Louis, MO, USA) after anaerobic incubation at $37{ }^{\circ} \mathrm{C}$ for $48 \mathrm{~h}$ in sealed jars 
containing an Anaerogen sachet (Oxoid, Basingstoke. Hants, UK) (Mucchetti et al. 2008). Enterococci were counted on Kanamycin aesculin azide agar (Merck) after incubation at $37{ }^{\circ} \mathrm{C}$ for $48 \mathrm{~h}$ (Dolci et al. 2007). Presumptive coagulase positive Staphylococcus aureus (colonies with an opaque zone) were counted on Baird Parker agar (Difco, NJ, USA) supplemented with egg yolk tellurite medium plates after incubation at $37{ }^{\circ} \mathrm{C}$ for $48 \mathrm{~h}$ (Psoni et al. 2003). Yeast and mould were determined on yeast glucose chloramphenicol agar (Difco) plates after incubation at $25^{\circ} \mathrm{C}$ for 5 days (Mucchetti et al. 2008). Coliforms were counted on double layer violet red bile agar (Difco) after incubation at $30{ }^{\circ} \mathrm{C}$ for $24 \mathrm{~h}$ (Psoni et al. 2003). Psychrotrophic bacteria were counted on skim milk plate count agar (Difco) after incubation at $7{ }^{\circ} \mathrm{C}$ for 10 days (Özdemir and Demirci 2006). Spread plate method was used for the enumeration of yeast, mould and presumptive coagulase positive Staphylococcus aureus. For the rest of the bacteria, pour plate method was used for enumeration. All analyses were carried out using duplicate plates at each dilution. After colony counting, the counts were expressed as log colony-forming unit (cfu) per gram of sample.

\section{Isolation of bacteria}

After incubation on MRS agar ( $\mathrm{pH}$ 6.2-6.8) and Kanamycin esculin azide agar ( $\mathrm{pH}$ 7.2), approximately 20 individual colonies from each plate having 30-300 colonies were selected (according to shape, size and colour) and transferred into sterile M17 (Merck) and MRS (Fluka) broth media. They were purified by two subsequent subcultures on Kanamycin esculin azide and MRS agars using the streak plate technique. Isolates that were purified were stored in MRS and M17 broth media, which contained 20\% (v/v) glycerol as frozen stocks at $-80{ }^{\circ} \mathrm{C}$ before being subjected to identification analysis. Glycerol stock samples were prepared by mixing $0.5 \mathrm{~mL}$ of overnight cultures, and $0.5 \mathrm{~mL}$ of $40 \%(\mathrm{v} / \mathrm{v})$ glycerol.

\section{Physiological and biochemical identification of isolates}

The catalase test and Gram stain were carried out to make sure that all isolates were lactic acid bacteria (Gram-positive and lacked catalase). Cell shapes and arrangements (such as individual colonies, pairs or clusters) and the results of Gram staining were examined under an oil immersion lens by light microscopy (Olympus CX31, Tokyo, Japan).

Overnight cultures grown in 5 -mL MRS broth at $30{ }^{\circ} \mathrm{C}$ were used for the identification procedures. For all tests, noninoculated media were used as a negative control. Tests for the ability to produce gas from glucose, growth at different temperatures $\left(10,40\right.$ and $45^{\circ} \mathrm{C}$ ), growth at different $\mathrm{NaCl}$ concentrations (20, 40 and $65 \mathrm{~g} / \mathrm{L})$, hydrolysis of arginine and gas production from citrate in Reddy broth were applied to cocci-shaped isolates for phenotypic identification. For the phenotypic identification of rod-shaped isolates, gas production from glucose, growth at 15 and $45^{\circ} \mathrm{C}$, growth in $65 \mathrm{~g} / \mathrm{L} \mathrm{NaCl}$ and arginine hydrolysis tests were performed. Then, carbohydrate fermentation tests were performed for species and subspecies level identification of isolates. Carbohydrate fermentation tests were performed in 96-well plates using the method described by Bulut (2003) and Bulut et al. (2005). The following 14 substrates; L $(+)$-arabinose, $\mathrm{D}(+)$-galactose, lactose, maltose, $\mathrm{D}(+)$-mannitol, raffinose, sucrose, $\mathrm{D}(-)$-salicin, sorbitol, $\mathrm{D}(+)$-trehalose, $\mathrm{D}(+)$-xylose, glycerol, $\mathrm{D}(+)$-mannose and $\mathrm{D}(-)$-ribose were used for the carbohydrate fermentation tests. Samples with glucose and samples without sugar were used as positive and negative controls, respectively. After 24-h incubation at $30{ }^{\circ} \mathrm{C}$, the carbohydrate fermentation abilities of isolates were measured at 615-nm absorbance using an automated microtiter plate reader (Thermo, Varioskan Flash, Finland). Sugar fermentation ability was determined based on turbidity and colour change from purple to yellow.

\section{Genotypic identification of isolates}

Two representative isolates from each group (Table 3) were chosen at random to obtain $16 \mathrm{~S}$ rDNA sequences. DNA was extracted from the overnight cultures grown in 6-mL MRS broth at $37{ }^{\circ} \mathrm{C}$. PureLink ${ }^{\mathrm{TM}}$ Genomic DNA Mini Kits (Catalogue Number K1820-02, Invitrogen ${ }^{\mathrm{TM}}$, Carlsbad, CA, USA) were used for purification of genomic DNA. After the DNA was purified by application of the method recommended by the manufacturer, the purified DNA was transferred to a new Eppendorf and stored at $-20{ }^{\circ} \mathrm{C}$.

Amplification of the $16 \mathrm{~S}$ rDNA was performed in a $20-\mu \mathrm{L}$ reaction mixture consisting of $5 \mu \mathrm{L}$ of genomic DNA, $2 \mu \mathrm{L}$ PCR buffer, $2 \mu \mathrm{L}$ dNTP mix ( $2 \mathrm{mM}$ each), $0.4 \mu \mathrm{L}$ of bacterial universal primer $10 \mathrm{mM}$ E334F (5'-CCAGACTCCTAC GGGAGGCAGC-3'), $0.4 \mu \mathrm{L}$ of bacterial universal primer $10 \mathrm{mM}$ E939R (5'-CTTGTGCGGGCCCCCGTCAATTC$\left.3^{\prime}\right), \quad 0.1 \mu \mathrm{L}$ Taq polymerase $(5 \mathrm{U} / \mu \mathrm{L}), 1.2 \mu \mathrm{L} \quad \mathrm{MgCl}_{2}$ $(25 \mathrm{mM})$ and sufficient water to make up the volume to $20 \mu \mathrm{L}$ (Baker et al. 2003). The amplification reaction was performed in a PCR (Biorad, C100 ${ }^{\mathrm{TM}}$ Thermo Cycler, Singapore) using the following conditions: predenaturation (3 min at $95{ }^{\circ} \mathrm{C}$ ) followed by 25 cycles of denaturation for $30 \mathrm{~s}$ at $94{ }^{\circ} \mathrm{C}$, annealing for $30 \mathrm{~s}$ at $62{ }^{\circ} \mathrm{C}$ and elongation for $1 \mathrm{~min}$ at $72{ }^{\circ} \mathrm{C}$, and the final cycle was followed by an additional extension for $5 \mathrm{~min}$ at $72{ }^{\circ} \mathrm{C}$ (Giraffa et al. 2000).

The amplified products were purified using Sephadex ${ }^{\mathrm{TM}}$ columns (MN Receiver Column, 740522.250, Düren, Germany, and Sigma S6022 Sephadex, Steinheim, Germany) and were then sequenced using the ABI Prism BigDye Terminator v3.1 Cycle Sequencing Kit with forward primer (E 334) in a single direction using an Applied Biosystems 3130xl Genetic Analyzer (Foster City, CA, USA). The sequence chromatograms were analysed by the Finch TV 1.4.0. program and compared with the GenBank database to determine sequence homology (Tan et al. 2010). 


\section{Statistical analysis}

Mean values, standard deviations, maximum and minimum values were calculated for all the parameters determined. Analysis of variance was performed to investigate the differences $(P<0.05)$ in microbiological counts during production and ripening. The Student-Newman-Keuls range test was applied for comparison of the mean values. Principal component analysis (PCA) is a statistical method to reduce the dimensionality of the data, to calculate the components that best described the differences between samples and to identify clusters (Smith 2002). In this study, PCA was used to obtain the first two principal components from the microbiological counts of the cheese samples and to identify the potential grouping of samples using Statistica software (StatSoft Inc., Tulsa, OK, USA).

Table 1 Microbiological counts (log cfu/g) based on analysis of 52 Sepet cheeses

\begin{tabular}{llllll}
\hline $\begin{array}{l}\text { Microbiological } \\
\text { analysis }\end{array}$ & Mean & Maximum & Minimum & $\begin{array}{l}\text { Standard } \\
\text { deviation }\end{array}$ & Variance \\
\hline $\begin{array}{l}\text { Total aerobic } \\
\text { bacteria }\end{array}$ & 7.53 & 9.03 & 5.52 & 1.13 & 1.28 \\
Lactococci & 7.31 & 8.89 & 5.49 & 1.08 & 1.16 \\
Lactobacilli & 7.19 & 8.74 & 5.30 & 1.02 & 1.05 \\
Enterococci & 6.84 & 8.87 & 5.44 & 0.92 & 0.85 \\
Yeast & 3.19 & 5.49 & $<1.00$ & 1.40 & 1.96 \\
Mould & 0.84 & 2.58 & $<1.00$ & 0.89 & 0.79 \\
Coliform & 2.18 & 5.51 & $<1.00$ & 1.81 & 3.29 \\
Psychrotrophic & 4.92 & 7.23 & 3.10 & 1.15 & 1.33 \\
$\quad$ bacteria & & & & & \\
$\begin{array}{l}\text { Staphylococcus } \\
\text { aureus }\end{array}$ & 1.25 & 4.61 & $<1.00$ & 1.70 & 2.87 \\
\hline
\end{tabular}

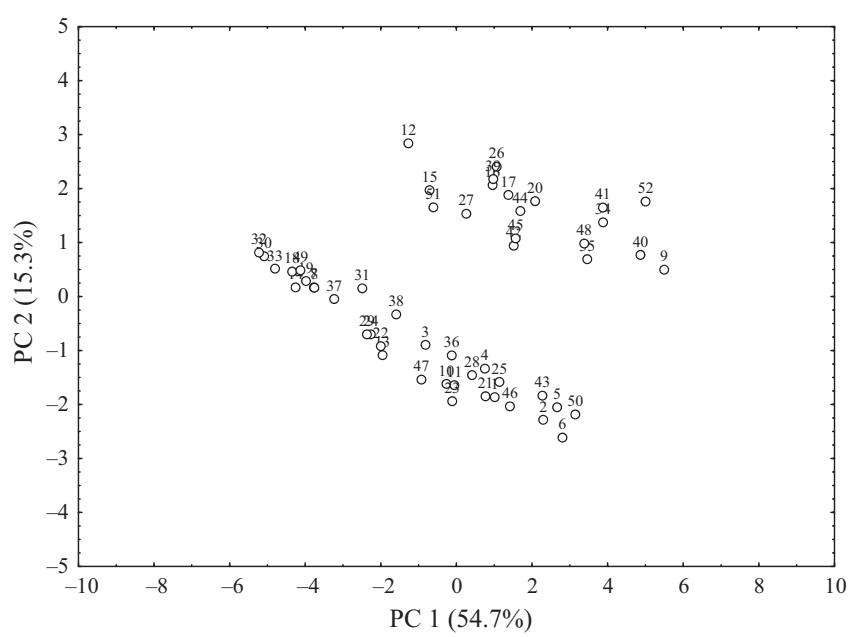

Figure 1 Score plot of the first two principal components of Sepet cheeses based on the microbiological counts.

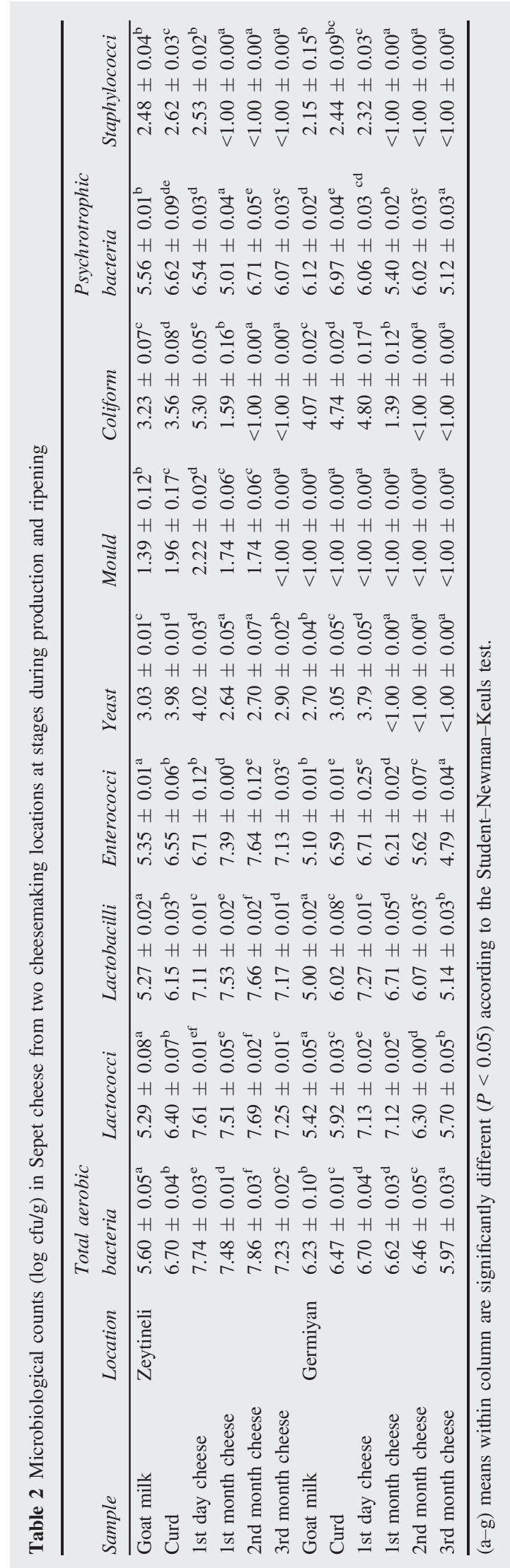




\section{RESULTS AND DISCUSSION}

\section{Microbiological counts of Sepet cheeses}

Variation in the microbiological counts of Sepet cheese samples is shown in Table 1. Maximum yeast, mould and coliform counts found were as 5.49, 2.58 and $5.51 \log \mathrm{cfu} /$ $\mathrm{g}$, respectively, while yeast, mould and coliforms were absent in some of the Sepet cheese samples. Coliforms are used as a general indicator of the sanitary condition of food-processing environments (Feng et al. 2002). Coliforms

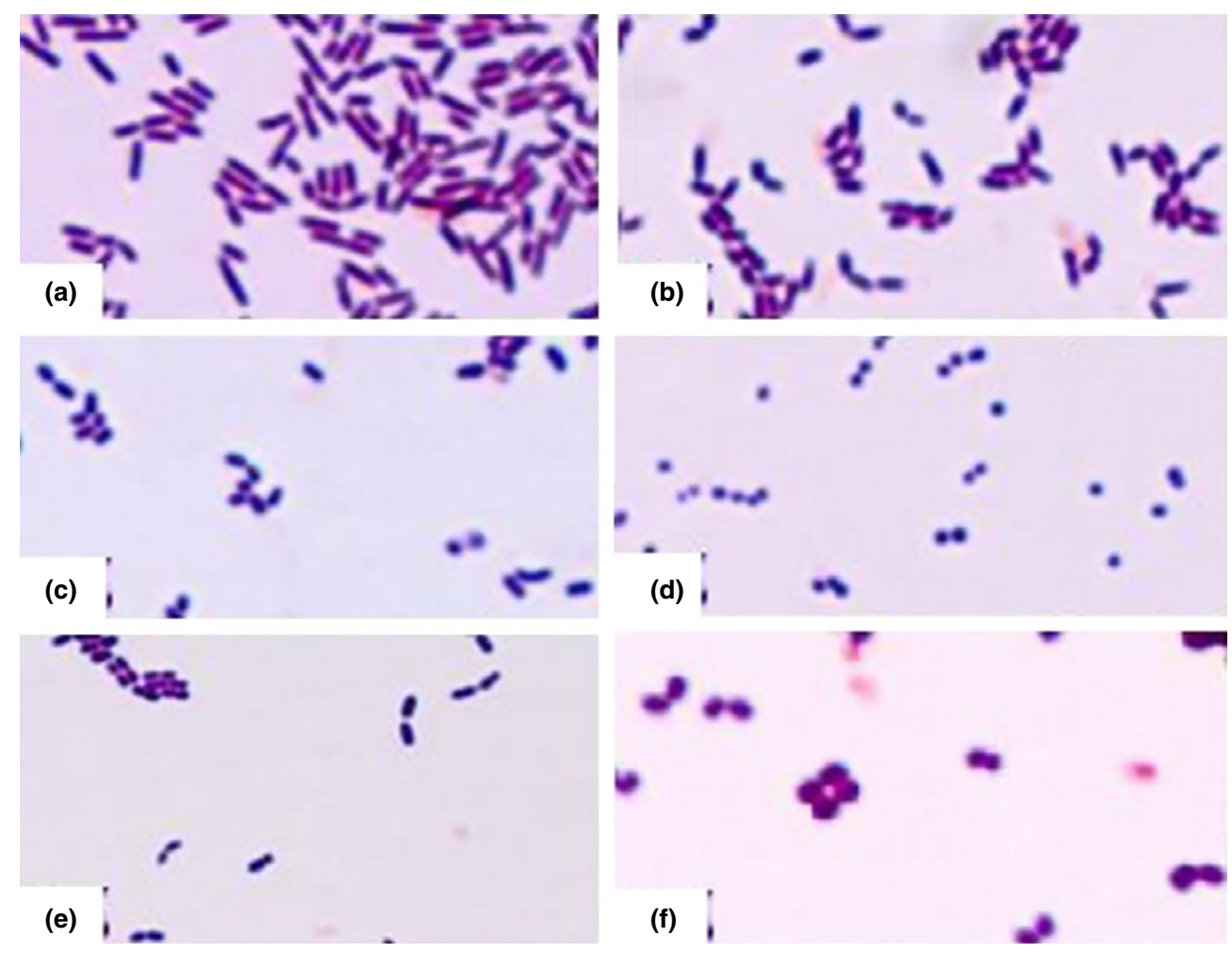

Figure 2 Cell morphology of isolated Lactobacillus plantarum (a), Weisella confusa (b), Weisella paramesenteroides (c), Enterococcus durans/faecium (d), Enterococcus casseliflavus (e) and Pediococcus pentasaceous (f).

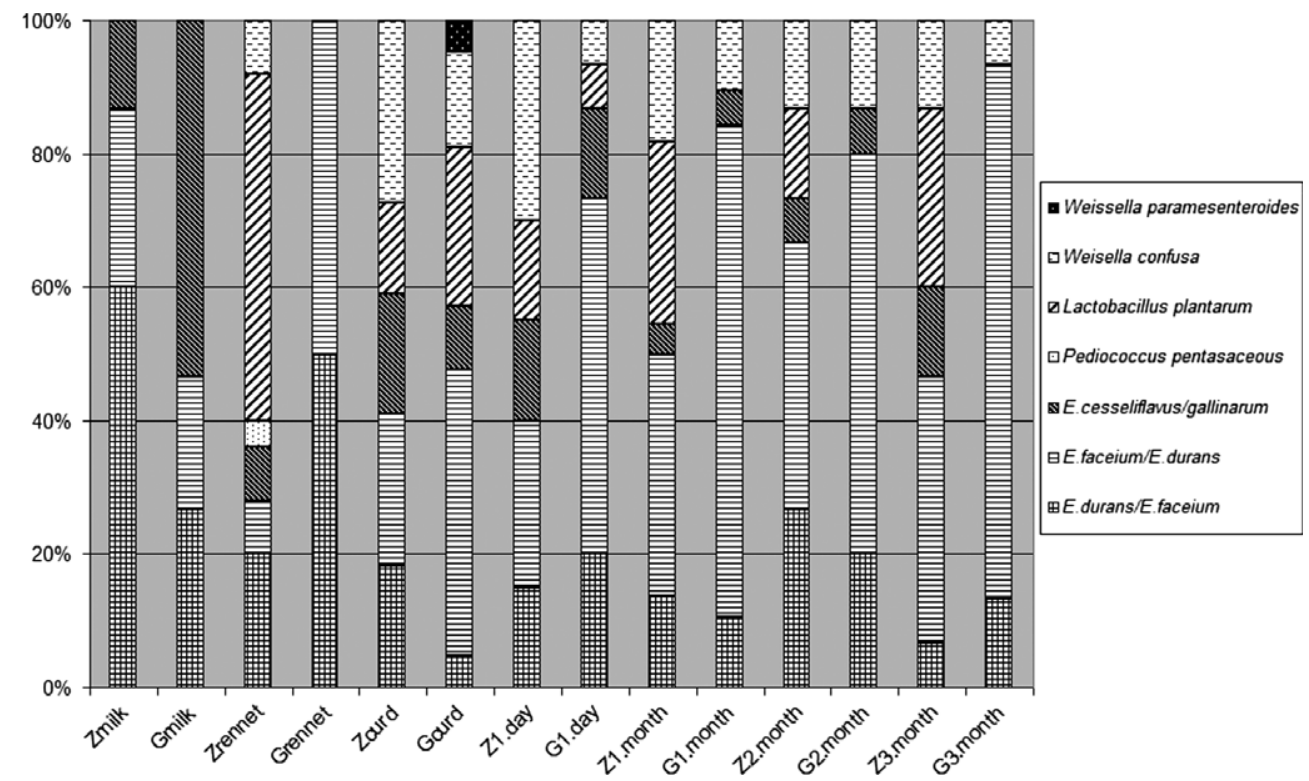

Figure 3 The percentages of isolated micro-organisms during production and ripening of Sepet cheeses. Z and G indicate the towns as Zeytineli and Germiyan, respectively. 
were detected in 35 of Sepet cheese samples. High coliform counts in Sepet cheese samples may be caused by the use of unpasteurised milk in the production, unsanitary production areas, postcontamination after production during marketing, etc. Nineteen Sepet cheese samples contained Staphylococcus aureus, and the maximum number counted was $4.61 \mathrm{log} \mathrm{cfu} / \mathrm{g}$. Hamid and Owni (2007) stated that high counts of S. aureus found in some cheese samples might be attributed to the high initial numbers of $S$. aureus in raw milk or contamination during processing. When the results are compared with previous artisanal cheese studies in Turkey, the coliform counts were lower than those reported for Örgü and Sikma cheeses. Turkoglu et al. (2003) and Ceylan et al. (2003) reported 3.73 and $5.99 \mathrm{log}$ $\mathrm{cfu} / \mathrm{g}$ coliforms in Örgü and Sikma cheeses, respectively. Kamber (2008b) reported that Mihaliç cheese had $3.30 \mathrm{log}$ cfu/g coliforms, $5.9 \mathrm{log} \mathrm{cfu} / \mathrm{g}$ lactococci and $7.69 \mathrm{log} \mathrm{cfu} / \mathrm{g}$ total aerobic counts. The Sepet cheese samples had total aerobic bacteria counts similar to Mihaliç cheese. Kamber and Çelik (2007) investigated the microbiological characteristics of Gorcola cheese and found that Gorcola cheese had $1.9 \times 10^{7} \mathrm{cfu} / \mathrm{g}$ total aerobic mesophilic bacteria, $2.9 \times 10^{4} \mathrm{cfu} / \mathrm{g}$ lactic acid bacteria, $1.0 \times 10^{7} \mathrm{cfu} / \mathrm{g}$ lactococci, $1.5 \times 10^{4} \mathrm{cfu} / \mathrm{g}$ coliforms and $1.4 \times 10^{5} \mathrm{cfu} / \mathrm{g}$ yeastmould count. Yeast and mould counts in Sepet cheeses were lower than the counts reported for Gorcola cheese. It was also observed that lactococci and total aerobic bacteria in Sepet cheese samples were higher than those reported for Gorcola cheese. The total aerobic bacteria counts for Sepet cheese samples found in this work were similar to those found by Kinık et al. (1999), but higher than those found by Karakaş and Korukluoğlu (2006). Moreover, Karakaş and Korukluoğlu (2006) found relatively higher yeast counts in their Sepet cheese samples.

The microbiological count data for fifty-two Sepet cheese samples were subjected to PCA. PCA is a tool to identify patterns in data to highlight their similarities and differences using an orthogonal transformation (Smith 2002). Figure 1 shows the score plot of the first two principal components (PC1 and PC2). These two PCs accounted for $70 \%$ of the total variance. Based on presumptive S. aureus counts, the cheese samples were separated into two clusters. The cheeses, which had higher $S$. aureus counts, were placed on the upper part of the plot. The cheeses, which had higher microbial loads, were placed on the right-hand side while the cheeses, which had lower microbial loads, were placed on the left-hand side of the plot in each cluster. The cheese samples (36\% of total cheese samples), which had relatively higher presumptive $S$. aureus counts, were mostly collected from local bazaars. This may be related to unsanitary conditions in transportation and storage in the bazaars.

Changes in the microbiological counts during the production and ripening of Sepet cheese made at two sites were also investigated. The microbiological counts are shown in Table 2. All bacterial counts increased during cheese production $(P<0.05)$ due to concentration associated with cheesemaking. An exception was mould counts in the cheese made at the Germiyan site. The Staphylococci, coliforms and mould counts of Sepet cheeses were less than $1.00 \mathrm{log} \mathrm{cfu} / \mathrm{g}$ at the end of ripening. Although yeast counts in Zeytineli cheese decreased until the 3rd month, their levels were higher than $1.00 \mathrm{log} \mathrm{cfu} / \mathrm{g}$ at the end of the ripening period. Ercan et al. (2011) investigated the physicochemical changes during production and ripening and reported that the $\mathrm{pH}$ decreased during production and ripening. The decrease in $\mathrm{pH}$ could affect the population of staphylococci and coliforms. Since mould and yeast could grow at a wide range of $\mathrm{pH}$ and acidity, the most important reason for decreases in yeast and mould counts during the ripening of cheese may be anaerobic conditions (Jay 1996). The results reported here are similar to the results of Kılıç et al. (2004). They found a significant decrease in staphylococci and coliform counts during the ripening of fresh Turkish goat cheese. Similar trends were also found in the studies on Valdeteja raw goat's milk cheese and Manchego cheeses (Calleja et al. 2002; Cabezas et al. 2007).

\section{Identification of isolates}

Lactic acid bacteria are essential for the fermentation and are acceptable in very large numbers in traditional cheeses made with raw milk (Hamid and Owni 2007). Lactic acid bacteria in Sepet cheese during production and ripening for up to the 3 months were examined. Isolates were chosen for identification after subculturing, Gram staining and catalase tests were performed. The morphologies of isolated microorganisms are given in Figure 2. A total 240 isolates (approximately 20 colonies from each plate) were identified. According to the identification results, the percentages of cocci and rods in samples of milk and during cheese ripening fluctuated. The ratios of identified bacteria during cheese production and ripening are shown in Figure 3. The artisanal rennet used in Zeytineli had a more diverse bacterial population than the commercial rennet used in Germiyan. Thus, the artisanal rennet might be responsible for higher counts of total aerobic bacteria, lactococci, lactobacilli and enterococci found in Zeytineli cheese (Table 2).

The phenotypic identification results are given in Table 3 . Enterococcus spp. were predominant during Sepet cheese production and ripening. Fox et al. (2000) stated that Enterococci have the ability to grow at the wide range of temperatures and salt contents found in Mediterranean cheeses. Based on the taxonomy of Devriese et al. (2006), $66.2 \%$ of total isolates in Sepet cheeses were closely related to Enterococcus species. Isolated enterococci were arginine hydrolyse positive, were able to grow at $6.5 \% \mathrm{NaCl}$ and had coccoid shapes. Due to mannitol fermentation ability of 
Table 3 Phenotypic characteristics of micro-organisms isolated from Sepet cheeses

\begin{tabular}{|c|c|c|c|c|c|c|c|c|c|c|c|c|c|c|c|c|}
\hline Shape & Catalase & $\begin{array}{l}2 \% \\
\mathrm{NaCl}\end{array}$ & $\begin{array}{l}4 \% \\
\mathrm{NaCl}\end{array}$ & $\begin{array}{l}6.5 \% \\
\mathrm{NaCl}\end{array}$ & $10^{\circ} \mathrm{C}$ & $15^{\circ} \mathrm{C}$ & $40^{\circ} \mathrm{C}$ & $45^{\circ} \mathrm{C}$ & $\begin{array}{l}\text { Arginine } \\
\text { hydrolysis }\end{array}$ & $\begin{array}{l}\mathrm{CO}_{2} \\
\text { in } \\
\text { Reddy } \\
\text { broth }\end{array}$ & $\begin{array}{l}\mathrm{CO}_{2} \\
\text { from } \\
\text { glucose }\end{array}$ & $\begin{array}{l}\text { Arab- } \\
\text { inose }\end{array}$ & $\begin{array}{l}\text { Gala- } \\
\text { ctose }\end{array}$ & Lactose & Ribose & Sorbitol \\
\hline Cocci & - & + & + & + & + & ND & + & + & + & - & - & + & + & + & + & - \\
\hline Cocci & - & + & + & + & + & ND & + & + & + & - & - & + & + & + & + & - \\
\hline Cocci & - & + & + & + & + & ND & + & + & + & - & - & + & + & + & + & - \\
\hline Cocci & - & + & + & + & + & ND & + & + & + & - & - & + & + & + & + & - \\
\hline Cocci & - & + & + & + & + & ND & + & + & + & - & - & + & + & + & + & \pm \\
\hline Cocci & - & + & + & + & + & ND & + & + & + & - & - & + & + & + & + & - \\
\hline Cocci & - & + & + & + & + & ND & + & + & + & - & - & + & + & + & + & - \\
\hline $\begin{array}{l}\text { Group } \\
\text { of four } \\
\text { or two } \\
\text { cocci }\end{array}$ & - & + & + & + & + & ND & + & + & + & - & - & + & + & + & + & - \\
\hline $\begin{array}{r}\text { Short } \\
\text { rods }\end{array}$ & - & ND & ND & + & ND & + & ND & + & + & ND & + & - & + & + & + & - \\
\hline $\begin{array}{r}\text { Short } \\
\text { rods }\end{array}$ & - & ND & ND & + & ND & + & ND & + & + & ND & + & \pm & + & + & + & - \\
\hline $\begin{array}{r}\text { Short } \\
\text { rods }\end{array}$ & - & ND & ND & + & ND & + & ND & + & + & ND & + & \pm & + & + & + & + \\
\hline $\begin{array}{r}\text { Short } \\
\text { rods }\end{array}$ & - & ND & ND & + & ND & + & ND & + & + & ND & + & - & + & + & + & \pm \\
\hline $\begin{array}{r}\text { Short } \\
\text { rods }\end{array}$ & - & ND & ND & + & ND & + & ND & + & + & ND & + & - & + & + & + & - \\
\hline $\begin{array}{r}\text { Short } \\
\text { rods }\end{array}$ & - & ND & ND & + & ND & + & ND & + & + & ND & + & \pm & + & + & + & - \\
\hline Lenticular & - & ND & ND & + & ND & + & ND & - & - & ND & + & + & + & + & + & - \\
\hline Rod & - & ND & ND & + & ND & + & ND & + & - & ND & - & - & + & + & + & + \\
\hline Rod & - & ND & ND & + & ND & + & ND & + & - & ND & - & \pm & + & + & + & + \\
\hline Rod & - & ND & ND & + & ND & + & ND & + & - & ND & - & \pm & + & + & + & + \\
\hline Rod & - & ND & ND & + & ND & + & ND & + & - & ND & - & + & + & + & + & + \\
\hline Rod & - & ND & ND & + & ND & + & ND & + & - & ND & - & + & + & + & + & + \\
\hline Rod & - & ND & ND & + & ND & + & ND & + & - & ND & - & + & + & + & + & + \\
\hline Rod & - & ND & ND & + & ND & + & ND & + & - & ND & - & \pm & + & + & + & + \\
\hline
\end{tabular}

ND indicates not determined. The sign of,, \pm+- indicate weak, positive and negative reactions, respectively.

E. faceium, the isolates of E. faceium can be differentiated from the isolates of E. durans (Collins et al. 1984; Farrow and Collins 1985; Cai 1999; Klein 2003). E. durans is differentiated from $E$. hirae because the former cannot ferment raffinose (Collins et al. 1984; Farrow and Collins 1985; Cai 1999; Klein 2003). E. casseliflavus is different from E. gallinarum based on the fermentation of glycerol, and sorbitol. E. casseliflavus is also differentiated from other Enterococcus species based on the ability to ferment D-xylose (Collins et al. 1984; Cai 1999). Bulut et al. (2005), TorresLlanez et al. (2006), Psoni et al. (2003) and Serhan et al. (2009) also isolated E. durans and E. faceium from artisanal raw milk cheeses.
Approximately $15 \%$ of total isolates were Lactobacillus spp. isolated during production and ripening of both cheeses. All Lactobacillus spp. were closely related to L. plantarum. L. plantarum is differentiated from L. farmcinis because it cannot hydrolyse arginine but it can ferment raffinose, mannitol and sorbitol. L. plantarum is differentiated from $L$. fermentum because it can ferment salicin, sorbitol and mannitol (Antara et al. 2002; Hammes and Hertel 2006 and Özkalp et al. 2009). Tserovska et al. (2002) also found $L$. plantarum in goat cheeses.

Based on the taxonomic data of Björkroth and Holzapfel (2006) and Björkroth et al. (2002), 13\% of total isolates from Sepet cheese were closely related to Weisella spp. 


\begin{tabular}{|c|c|c|c|c|c|c|c|c|c|c|c|}
\hline Salicin & Raffinose & Mannitol & Mannose & Xylose & Maltose & Trehalose & Glycerol & Sucrose & Glucose & $\begin{array}{l}\text { \% Similarity with the } \\
\text { microorganisms in the } \\
\text { GenBank database } \\
\text { with accession \# }\end{array}$ & Species \\
\hline+ & - & - & + & - & + & \pm & - & - & + & 96, HE646381 & Enterococcus durans \\
\hline+ & - & - & + & - & + & \pm & - & \pm & + & 96, JQ366081 & Enterococcus durans \\
\hline+ & - & \pm & + & - & + & + & - & + & + & 96, GU904685 & Enterococcus faceium \\
\hline+ & - & + & + & - & + & + & - & - & + & 96, HQ616645 & Enterococcus faceium \\
\hline+ & - & + & + & - & + & + & - & - & + & 94, JQ712023 & Enterococcus faceium \\
\hline+ & - & \pm & + & - & + & + & - & - & + & 97, HE646396 & Enterococcus faceium \\
\hline+ & + & + & + & + & + & + & - & \pm & + & 96, JN645289 & $\begin{array}{l}\text { Enterococcus } \\
\text { casseliflavus }\end{array}$ \\
\hline+ & - & - & + & - & + & + & - & - & + & 96, JQ712016 & $\begin{array}{l}\text { Pediococcus } \\
\text { pentasaceous }\end{array}$ \\
\hline \pm & - & \pm & + & + & + & + & - & + & + & 96, JQ801710 & Weissella confusa \\
\hline \pm & - & \pm & + & + & + & + & - & + & + & 97, JF757231 & Weissella confusa \\
\hline+ & - & + & + & + & + & + & - & + & + & 95,HQ711354 & Weissella confusa \\
\hline \pm & - & \pm & + & + & + & + & - & + & + & 92, AB494723 & Weissella confusa \\
\hline- & - & - & + & + & + & + & - & + & + & 93, JQ801709 & Weissella confusa \\
\hline \pm & - & \pm & + & + & + & + & - & + & + & 96, JQ801710 & Weissella confusa \\
\hline- & - & + & + & - & + & + & - & + & + & 96, HQ721270 & $\begin{array}{l}\text { Weissella } \\
\text { paramesenteroides }\end{array}$ \\
\hline+ & - & + & + & \pm & + & + & - & + & + & 95, JN863662 & Lactobacillus plantarum \\
\hline+ & - & + & + & \pm & + & + & - & + & + & 95, HE646362 & Lactobacillus plantarum \\
\hline+ & - & + & + & \pm & + & + & - & \pm & + & 96, HE616213 & Lactobacillus plantarum \\
\hline+ & \pm & + & + & + & + & + & - & + & + & 96, JQ580990 & Lactobacillus plantarum \\
\hline+ & - & + & + & + & + & + & - & + & + & 97, HE646413 & Lactobacillus plantarum \\
\hline+ & \pm & + & + & \pm & + & + & - & + & + & 95, JN863682 & Lactobacillus plantarum \\
\hline+ & \pm & + & + & \pm & + & + & \pm & + & + & 97, HE616210 & Lactobacillus plantarum \\
\hline
\end{tabular}

W. paramesenteroides has a lenticular shape. It cannot grow at $45{ }^{\circ} \mathrm{C}$ and cannot hydrolyse arginine. W. paramesenteroides is differentiated from $W$. hellica by the ability to ferment galactose and trehalose (Björkroth and Holzapfel 2006). Weisella confusa (Lactobacillus confusus) is differentiated from $W$. ciberia because it cannot ferment arabinose but has the ability to ferment ribose and galactose. W. ciberia and W. confusa are also differentiated from other Weisella species because they can ferment D-xylose (Björkroth et al. 2002; Björkroth and Holzapfel 2006).

Pediococcus spp. were only isolated from artisanal rennet. The isolates were closely related to $P$. pentasaceous. $P$. pentasaceous is differentiated from Pediococcus acidilac- tici because it can ferment arabinose, trehalose and maltose (Tserovska et al. 2002; Holzapfel et al. 2006).

Forty phenotypically identified isolates were selected for genotypic identification. The results of genotypic identification analysis were in agreement with the results of phenotypic identification analyses. The $16 \mathrm{~S}$ rDNA sequences of micro-organisms isolated from Sepet cheese were similar to isolates found in Western Balkan traditional cheese, probiotic isolates from traditional dairy products of the Azarbayjan region, isolates from kefir, isolates from Altiplano Cundiboyacense (a traditional handmade double cream cheese), isolates from Caciocavallo Palermitano cheese and from artisanal Vlasina raw milk goat cheeses, which were 
reported in the GenBank database. The percentage similarity and the accession number of similar micro-organisms in GenBank database are given in Table 3.

\section{CONCLUSIONS}

In all Sepet cheese samples, lactococci, lactobacilli and enterococci were the predominant bacteria. Considerable variation was found in the microflora of Sepet cheese obtained from different sources in Aegean region of Turkey. Eight of the Sepet cheese samples did not contain mould and coliforms; this can be an indication of a good standard of hygiene during production and ripening. However, presumptive coagulase positive $S$. aureus was found in $36 \%$ of Sepet cheese samples, which is a public health concern.

According to phenotypic and genotypic identifications, two-thirds of isolates were closely related to Enterococci species including E. casseliflavus, E. durans and E. facei$u m$. Other isolates were identified as L. plantarum, W. confusa, $W$. paramesenteroides and $P$. pentasaceous.

When a batch of cheese from each of two farms was monitored during production and ripening, it was observed that total aerobic bacteria, lactococci, lactobacilli and enterococci counts decreased after the 1 st month $(P<0.05)$. Moreover, staphylococci and coliform counts decreased below $1.00 \mathrm{log} \mathrm{cfu} / \mathrm{g}$ before the end of the ripening period. Thus, the traditional ripening process appears to contribute to microbiological and pathogen control.

\section{ACKNOWLEDGEMENTS}

This research was supported by the Research Funds of Izmir Institute of Technology (Project no 2008-IYTE-17). The authors would like to thank Biotechnology and Bioengineering Application and Research Center of Izmir Institute of Technology for allowing us to use Applied Biosystems 3130xl Genetic Analyzer. The authors also thank Prof. Özer Kınık at Dairy Technology Department in Ege University and Assoc. Prof. H. Çağlar Karakaya at Molecular Biology and Genetics Department in Izmir Institute of Technology for helping to collect cheese samples and Assist. Prof. Alper Arslanoğlu at Molecular Biology and Genetics Department in İzmir Institute of Technology for giving advice in genotypic isolation of the lactic acid bacteria.

\section{REFERENCES}

Abdi R, Sheikh-Zeinoddin M and Soleimanian-Zad S (2006) Identification of lactic acid bacteria isolated from traditional Iranian lighvan cheese. Pakistan Journal of Biological Sciences 9 99-103.

Antara N S, Sujaya I N, Yokota A, Asano K, Aryanta W R and Tomita F (2002) Identification and succession of lactic acid bacteria during fermentation of 'urutan', a Balinese indigenous fermented sausage. World Journal of Microbiology \& Biotechnology 18 255-262.
Baker G C, Smith J J and Cowan D A (2003) Review and re-analysis of domain-specific $16 \mathrm{~S}$ primers. Journal of Microbiological Methods $\mathbf{5 5}$ 541-555.

Ballesteros C, Poveda J M, González-Viňas M A and Cabezas L (2006) Microbiological, biochemical and sensory characteristics of artisanal and industrial Manchego cheeses. Food Control 17 249-255.

Beresford T and Williams A (2004) The Microbiology of Cheese Ripening. In Cheese, Chemistry, Physics and Microbiology, pp 287-317. Fox P F, McSweeney P L H, Cogan T M and Guinee T, eds. California: Elsevier Academic Press.

Björkroth J and Holzapfel W H (2006) Genera Leuconostoc, Oenococcus and Weissella. In The Prokaryotes, Vol 4, pp 267-319. Dworkin M, ed. New York: Springer.

Björkroth K J, Schillinger U, Geisen R, Weiss N, Hoste B, Holzapfel W H, Korkeala H J and Vandamme P (2002) Taxonomic study of Weissella confusa and description of Weissella cibaria sp. nov., detected in food and clinical samples. International Journal of Systematic and Evolutionary Microbiology 52 141-148.

Boubekri K and Ohta Y (1996) Identification of lactic acid bacteria from Algerian traditional cheese, El-Klila. Journal of the Science of Food and Agriculture 70 501-505.

Büke E (1981) Sepet Cheese. Izmir: Ege University Agricultural Faculty Technology Department Graduation Thesis.

Bulut Ç (2003) Isolation and Molecular Characterization of Lactic Acid Bacteria from Cheese. İzmir: Master thesis in İzmir Institute of Technology.

Bulut C, Gunes H, Okuklu B, Harsa S, Kilic S, Coban H S and Yenidunya A F (2005) Homofermentative lactic acid bacteria of a traditional cheese, Comlek peyniri from Cappadocia region. Journal of Dairy Research 72 19-24.

Cabezas L, Sánchez I, Poveda J M, Sesenã S and Palop M L (2007) Comparison of microflora, chemical and sensory characteristics of artisanal Manchego cheeses from two dairies. Food Control 18 11-17.

Cai Y (1999) Identification and characterization of enterococcus species isolated from forage crops and their influence on silage fermentation. Journal of Dairy Science 82 2466-2471.

Calleja A, Carballo J, Capita R, Bernardo A and Garcia-Lopez M L (2002) Changes in the microflora of Valdeteja raw goat's milk cheese throughout manufacturing and ripening. Lebensmittel-Wissenschaft und-Technologie 35 222-232.

Ceylan Z G, Türkoğlu H and Dayısoylu K S (2003) The microbiological and chemical quality of sikma cheese produced in Turkey. Pakistan Journal of Nutrition 2 95-97.

Collins M D, Jones D, Farrow J A E, Kilpper-Balz R and Schleifer K H (1984) Enterococcus avium nom. rev., comb. nov.; E. casselipavus norn. rev., comb. nov.; E. durans norn. rev., comb. nov.; E. Gallinarum comb. nov.; and E. malodoratus sp. nova. International Journal of Systematic Bacteriology 34 220-223.

Crow V, Curry B and Hayes M (2001) The ecology of non-starter lactic acid bacteria (NSLAB) and their use as adjuncts in New Zealand Cheddar. International Dairy Journal 11 275-283.

Devriese L, Baele M and Butaye P (2006) The Genus Enterococcus: Taxonomy. In The Prokaryotes, Vol 4, pp 163-174. Dworkin M, ed. New York: Springer.

Dolci P, Alessandria V, Rantsiou K, Rolle L, Zeppa G and Cocolin L (2007) Microbial dynamics of Castelmagno PDO, a traditional Italian cheese, with a focus on lactic acid bacteria ecology. International Journal of Food Microbiology 122 302-311. 
Dost A, Yenikan H, Okumuş F and Işıklı N D (2004) Bazı geleneksel peynirlerin üretim yöntemleri. Van: Geleneksel Gidalar Sempozyumu.

Ercan D, Korel F, Karagül Yüceer Y and Kınık Ö (2011) Physicochemical, textural, volatile, and sensory profiles of traditional Sepet cheese. Journal of Dairy Science 94 4300-4312.

Farrow J A E and Collins M D (1985) Enterococcus hirae, a new species that includes amino acid assay strain NCDO 1258 and strains causing growth depression in young chickens. International Journal of Systematic Bacteriology 35 73-75.

Feng P, Stephen D, Grant M A and Burkhardt W (2002) BAM: Enumeration of Escherichia coli and the Coliform Bacteria. http://www.fda. gov/Food/FoodScienceResearch/LaboratoryMethods/ucm064948.htm

Fox P F, Guinee T P, Cogan T M and McSweeney P L H (2000) Pathogens and food-poisoning bacteria in cheese. In Fundamentals of Cheese Science, pp 500-501. Gaithersburg, Maryland: Aspen Publishers.

Giraffa G (2003) Functionality of enterococci in dairy products. International Journal of Food Microbiology 88 215-222.

Giraffa G, Rossetti L and Neviani E (2000) An evaluation of chelexbased DNA purification protocols for the typing of lactic acid bacteria. Journal of Microbiological Methods 42 175-184.

Hamid O I A and Owni O A O E (2007) Microbiological properties and sensory characteristics of white cheese (Gibna bayda) collected in Zalingei Area, West Darfur State. Research Journal of Animal and Veterinary Sciences 2 61-65.

Hammes W P and Hertel C (2006) The Genera Lactobacillus and Carnobacterium. In The Prokaryotes, Vol 4, pp 320-403. Dworkin M, ed. New York: Springer.

Holzapfel W H, Franz C M A P, Ludwig W, Back W and Dicks L M T (2006) The Genera Pediococcus and Tetragenococcus. In The Prokaryotes, Vol 4, pp 229-266. Dworkin M, ed. New York: Springer.

IDF (1981) International Dairy Federation Catalogue of Cheeses. International Dairy Federation Bull. Doc. 141. Brussels, Belgium: International Dairy Federation.

Jay M J (1996) Intrinsic and extrinsic parameters of foods that affect microbial growth. In Modern Food Microbiology, pp 35-56. NY: Chapman \& Hall.

Kamber U (2008a) The traditional cheeses of Turkey: the Aegean region. Food Reviews International 24 39-61.

Kamber U (2008b) The traditional cheeses of Turkey: Marmara Region. Food Reviews International 24 175-192.

Kamber U and Çelik T H (2007) Some microbiological and chemical characteristics of Gorcola cheese. Yüzüncü Yll University Veterinary Faculty Journal 18 87-92.

Karakaş R and Korukluoğlu M (2006) Geleneksel bir peynirimiz: sepet peynirinin kimyasal ve mikrobioyolojik özellikleri. Grda 31 169-172.

Kılıç S, Uysal H, Kavas G, Akbulut N and Kesenkaş H (2004) Manufacture and some properties of Turkish fresh goat cheese. Pakistan Journal of Biological Science 7 1037-1039.

Kınık Ö, Ergüllü E and Akbulut N (1999) A study on the production and some characteristics of Sepet cheese. Glda 24 151-161.
Klein G (2003) Taxonomy, ecology and antibiotic resistance of enterococci from food and the gastro-intestinal tract. International Journal of Food Microbiology 88 123-131.

Mucchetti G, Remagni C M, Ghiglietti R et al. (2008) Influence of cheese-making technology on composition and microbiological characteristics of Vastedda cheese. Food Control 19 119-125.

Özdemir C and Demirci M (2006) Selected microbiological properties of kashar cheese samples preserved with potassium sorbate. International Journal of Food Properties 9 515-521.

Özkalp B, Aladă̆ M O, Ögel Z, Özcan M M and Çelik B (2009) Determination of some metallic antimicrobial activities and plasmid and DNA prophiles of Lactobacillus strains isolated from fermented Caper pickle. World Applied Sciences Journal 6 347-354.

Pisano M B, Fadda M E, Deplano M, Corda A and Cosentino S (2006) Microbiological and chemical characterization of Fiore Sardo, a traditional Sardinian cheese made from ewe's milk. International Journal of Dairy Technology 59 171-179.

Psoni L, Tzanetakis N and Litopoulou-Tzanetaki E (2003) Microbiological characteristics of Batzos, a traditional Greek cheese from raw goat's milk. Food Microbiology 20 575-582.

Serhan M, Cailliez-Grimal C, Borges F, Revol-Junelles A-M, Hosri C and Fanni J (2009) Bacterial diversity of Darfiyeh, a Lebanese artisanal raw goat's milk cheese. Food Microbiology 26 645-652.

Smith L I (2002) A Tutorial on Principal Components Analysis. http:// www.cs.otago.ac.nz/cosc453/student_tutorials/principal_components. pdf.

Tan Z, Pang H, Duan Y, Qin G and Cai Y (2010) 16S ribosomal DNA analysis and characterization of lactic acid bacteria associated with traditional Tibetan Qula cheese made from yak milk. Animal Science Journal 81 706-713.

Terzic-Vidojevic A, Vukasinovic M, Veljovic K, Ostojic M and Topisirovic L (2007) Characterization of microflora in homemade semihard white Zlatar cheese. International Journal of Food Microbiology $11436-42$.

Torres-Llanez M J, Vallejo-Cordoba B, Díaz-Cinco M E, MazorraManzano M A and González-Córdova A F (2006) Characterization of the natural microflora of artisanal Mexican Fresco cheese. Food Control 17 683-690.

Tsakalidou E, Manolopoulou E, Tsilibari B, Georgalaki M and Kalantzopoulos G (1993) Esterolytic activities from Enterococcus durans and Enterococcus faecium strains isolated from Greek cheese. Netherlands Milk Dairy Journal 47 145-150.

Tserovska L, Stefanova S and Yordanova T (2002) Identification of lactic acid bacteria isolated from katyk, goat's milk and cheese. Journal of Culture Collections 3 48-52.

Turkoglu H, Ceylan Z G and Dayisoylu K S (2003) The microbiological and chemical quality of Orgu cheese produced in Turkey. Pakistan Journal of Nutrition 2 92-94.

Williams A G and Withers S E (2010) Microbiological characterization of artisanal farmhouse cheeses manufactured in Scotland. International Journal of Dairy Technology 63 356-369. 